\title{
Knowledge, opinions and attitudes of Polish women towards banking and donation of human breast milk
}

\author{
Julia M. Smyk ${ }^{1}{ }^{\oplus}$, Joanna Pergol ${ }^{1}$, Zuzanna Danielecka' ${ }^{1}$, Joanna P. Kacperczyk-Bartnik ${ }^{2} \oplus^{\circ}$,

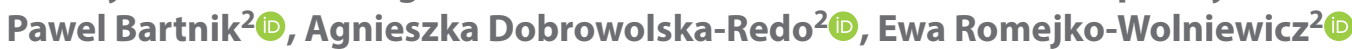 \\ 'Students' Scientific Group affiliated to $2^{\text {nd }}$ Department of Obstetrics and Gynaecology, Medical University of Warsaw, Poland \\ ${ }^{2} 2^{\text {nd }}$ Department of Obstetrics and Gynecology, Medical University of Warsaw, Poland
}

\begin{abstract}
Objectives: The aim of the study was to obtain information on the knowledge, opinions and attitudes of Polish women in terms of functioning of human milk banks, as well as the possibility to be a donor. Specific objectives included consideration of responses in the sociodemographic aspect and identification of factors influencing donation decisions.

Material and methods: A cross-sectional survey was conducted, obtaining 871 responses. Women were asked to provide basic sociodemographic data, information related to pregnancy and lactation. Knowledge and opinion about breast milk banks as well as the impact of various factors on a potential donation decision were investigated.

Results: Of all women participating in the study, 604 (69\%) were aware of the breast milk banks existence. $69 \%$ of respondents indicated the Internet, $10 \%$ - a nurse or midwife, while only $4 \%$ - a doctor as source of knowledge about human breast milk donation. Among women who had children $(n=453)$, only $9(2 \%)$ donated breast milk in the past. The indicated reasons for not donating were no milk excess (38\%), insufficient knowledge about the procedure or unawareness of its existence (33\% and $25 \%$, respectively), long distance to affiliated facility ( $17 \%)$.

Conclusions: The awareness of breast milk banks existence, possibilities and terms of donation in the studied group is not satisfactory. Widely sharing reliable information on banking and promoting the idea of donating human breast milk in society can lead to impressive results. There is a need for further development of human breast milk banks and continuous improvement of their availability in Poland.
\end{abstract}

Key words: breast feeding; lactation; milk banks

Ginekologia Polska 2021; 92, 11: 784-791

\section{INTRODUCTION}

According to the recommendations of the World Health Organization (WHO), breast milk from a professional milk bank is the second most advised nourishment for newborns and infants, after their own mother's milk [1]. In premature infants and newborns with low birth weight fed with mother's milk, the risk of developing necrotizing enterocolitis is two times lower than in their peers fed with baby formula [2]. The administration of natural milk, despite being pasteurized and processed, gives an advantage over baby formula in terms of earlier start of enteral nutrition, improvement of intestinal growth and maturation. Studies indicate a reduced risk of developing late onset sepsis, better neurodevelopmental outcomes, lower prevalence of retinopathy of prematurity and better development of their sight $[3,4]$. Women's breast milk for a sick or premature infant can be treated as a medicine containing antibodies and unique nutrients that cannot be administered in the form of baby formula [5]. Such organizations as: National Association of Neonatal Nurses [7] , the US Department of Health and Social Services [8], American Academy of Pediatrics [9] and European Society of Pediatric Gastroenterology, Hepatology and Nutrition [10] recommend the administration of milk from donors in a situation where there is lactation insufficiency, breast milk is inappropriate (e.g. during HIV or HTLV infection [6]), or when the mother uses medications contraindicated during breastfeeding.

As defined by the European Milk Bank Association the breast milk banks are facilities engaged in the acquisition, storage, processing and distribution of milk. Donor's milk is pumped breast milk, which was transferred free of charge to the Human Breast Milk Bank, to provide nourishment to 
needy newborns [4]. There are currently 248 breast milk banks operating in Europe, of which 16 are active in Poland. Cities with active facilities are Warsaw (2), Rzeszow (2), Torun, Wroclaw, Cracow, Opole, Ruda Slaska, Poznan, Szczecin, Gdansk, Gdynia, Zielona Gora, Lodz and Lublin [11].

A milk donor must meet both formal and health criteria for qualification. These include age of 18 and over, breastfeeding one's own child/children, consent to the processing of milk excess by the bank, medical interview, blood serological tests, compliance with the established procedure for expressing a nourishment, storage and use of lactation equipment, and no exposure to toxic compounds [5]. All tests and medical consultations related to the recruitment and donation of milk are free of charge for a donor. The interview is conducted in accordance with the Honour Milk Donor Card at the appropriate facility [6]. According to the European Milk Bank Association, the decision related to donation is the result of altruism and the women's willingness to help others, so motivation should not be associated with collecting commission that could lead to abuse [11].

\section{Objectives}

The following study was aimed at obtaining information on the knowledge, opinions and attitudes of Polish women in terms of functioning of Human Milk Banks, as well as the possibility to be a donor. Specific objectives included consideration of responses in sociodemographic aspect and identification of factors influencing donation decisions.

\section{MATERIAL AND METHODS}

A cross-sectional survey was conducted, obtaining 871 responses of Polish women. An original questionnaire was used and made available on Internet forums as well as distributed in paper form to patients of the obstetrics and gynaecology hospital of the third referral level and in several workplaces between December 2019 and February 2020.

The questionnaire consisted of 52 single- and multiple-choice, semi-open and open-ended questions. The set of questions was variable and narrowed depending on the previous answers of the respondent. The frequency and percentage of valid answers for individual questions are presented in the tables. In the beginning, the respondents were asked to provide basic sociodemographic data as well as information related to pregnancy and lactation. Then, in single-choice questions, the general knowledge of Polish women about breast milk banks was checked. Multiple choice questions were used to verify the detailed knowledge. Opinion on breast milk banking was also examined as well as the impact of various factors on a potential donation decision. In the study, the diagnostic survey method was used. Participation was anonymous and voluntary, and consent was given by completing the questionnaire.
Statistical analysis of the test results was performed in the IBM SPSS Statistics program. The presentation of variables included the following descriptive statistics: number of valid cases, mean, standard deviation, minimum, maximum, valid percentage and cumulative percentage. The Shapiro-Wilk test was used to examine the normality of the distribution. In a statistical analysis the chi-square test was used with the $p$ value of 0.05 .

\section{RESULTS}

The detailed characteristics of the study group are presented in Table 1.

Of all women participating in the study, 604 (69.35\%) were aware of the breast milk banks existence (Tab. 2).

Questions checking the general and detailed knowledge were asked to this group of respondents. Only $4.30 \%$ of women knew where the donor's milk was collected. Furthermore, only $10.76 \%$ knew how many breast milk banks exist in Poland. Finally, $61.26 \%$ of Polish women were aware parents of the newborn do not have to pay for milk from the bank.

The awareness of Polish women regarding permanent contraindications to donation was also examined. Only $7.62 \%$ of women were aware of the lack of opportunity to donate milk to the bank in case of a vegan diet, with a relatively high percentage of correct answers related to cigarette smoking (90.89\%) and HIV infection (86.26\%). It was also checked where the Polish women learned about breast milk banking. A total of $68.71 \%$ of them indicated the Internet, $10.26 \%$ - a nurse or midwife, while $3.97 \%$ - a doctor. Polish women who declared as a source of information a nurse or midwife, significantly more often knew who could become a milk donor $(p=0.034)$.

Women were also asked to subjectively assess their level of knowledge (Tab. 2). None of the respondents gave the "very good" answer. All respondents were asked about the willingness to broaden their knowledge on breast milk banking. It was checked which methods they would most like to use. Approximately $57.18 \%$ of them expressed a willingness to broaden knowledge; $83.13 \%$ would search for information on the Internet; $21.69 \%$ would ask a gynaecologist and only $8.84 \%$ would ask a general physician.

The awareness of the need for donation was also examined. $81.95 \%$ of women believed administering bank milk was a procedure that saved the life and health of the newborn, and $79.14 \%$ thought that the number of donors was not sufficient in relation to the demand for bank milk. At the same time, almost all respondents noted that knowledge about breast milk banking is not sufficiently widespread in Poland.

Four hundred fifty-three women, who in the first part of the survey indicated that they had children, were asked if they ever gave milk to a bank during lactation (Tab. 3). 


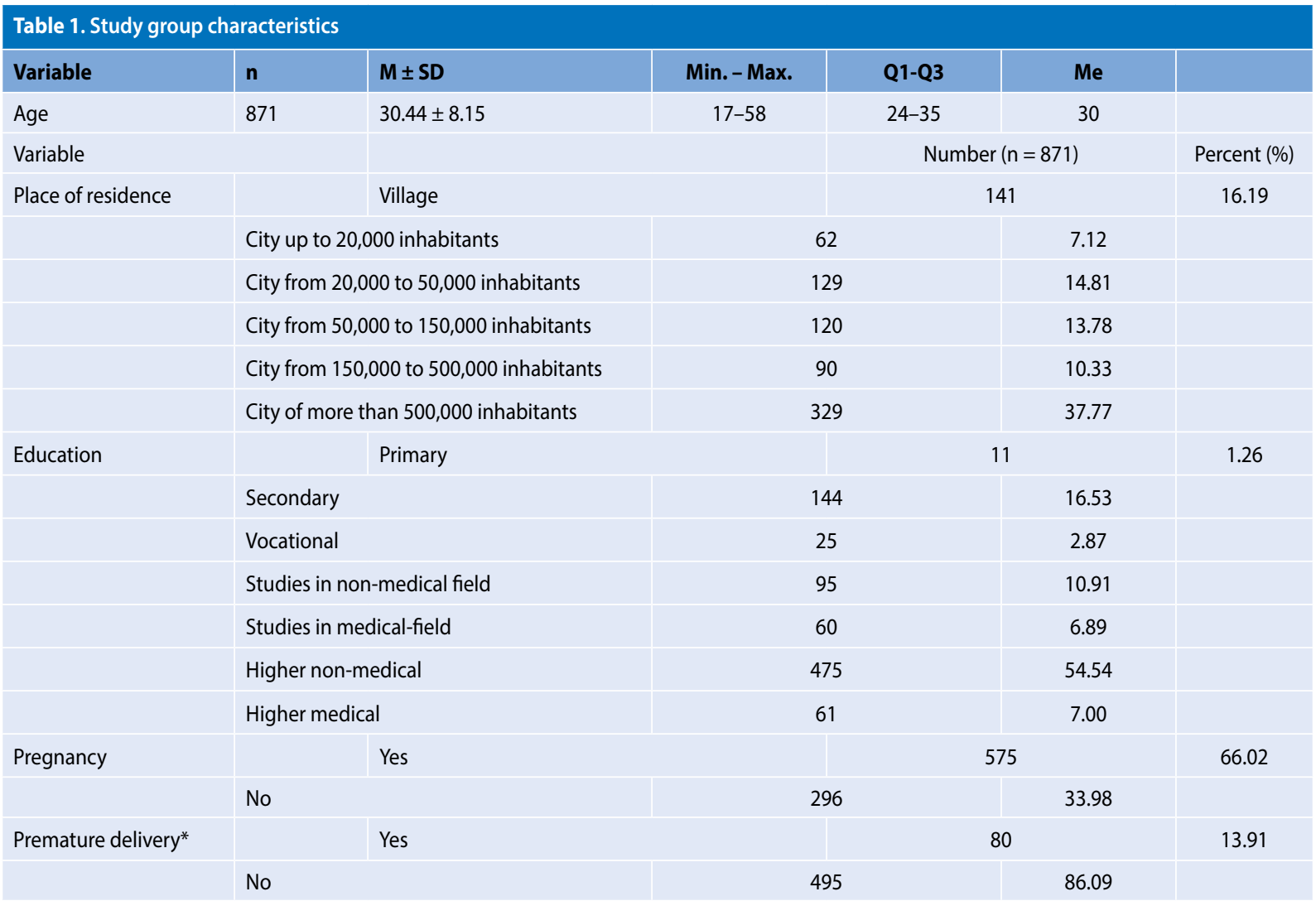

*575 respondents were surveyed. who answered "yes" for question "pregnancy"; $n$ - number of valid cases; $M \pm S D$ - mean \pm standard deviation; Min.-Max. - minimum-maximum; Q1-Q3 - lower-upper quartile; Me - median

Only 9 (1.99\%) respondents gave positive answers. Another $77.78 \%$ of them admitted that they decided to donate for altruistic reasons. The reasons for the failure to donate by $98.01 \%$ of Polish women were also analysed. $32.66 \%$ indicated insufficient knowledge about this procedure as the reason.

One hundred fifty-one childless women were asked about the willingness to donate milk in the future and the motivations for their decisions (Tab. 4). A total of $84.77 \%$ of respondents expressed the will to donate, in $96.09 \%$ of respondents the motivation was altruism. Among women who would not like to donate milk, $68.07 \%$ indicated that they had insufficient knowledge about the procedure.

A list of factors was presented to childless respondents and those with children, checking whether they would be more likely to donate (Tab. 5). Also, $84.11 \%$ of Polish women admitted that they would be encouraged to donate milk with more extensive knowledge about the procedure, and $80.96 \%$ of them would likely donate milk if they could do it in the nearest hospital.

A statistically significant relationship between the educational level, place of residence and the awareness of breast milk banks existence was investigated (Tab. 6 and Tab. 7). Most often, women living in cities exceeding 500,000 of inhabitants and respondents with higher medical education had heard of breast milk banks. Most rarely, those respondents living in the villages and having basic education were aware of the topic.

\section{DISCUSSION}

In the recent years, many publications have been released which prove the wide benefits of feeding with natural milk. Defining a breast milk as a drug led to the search for a safe way to collect and share it with sick and premature infants. This resulted in the establishment of the Women's Milk Bank in Poland. The institution was established to operate on March 28 ${ }^{\text {th }}, 2012$ in Warsaw [6]. During the following years, several social campaigns about breast milk banking were conducted. Huge efforts were made to increase the number of active facilities.

The knowledge, opinions and attitudes of women on breast milk banks around the world are varied. This is due to religious, ethical and environmental considerations. The level of education in this scope and access to appropriate medical infrastructure play a particularly important role in shaping attitudes. Verification of awareness and level of knowledge in the scope of breast milk banking seems therefore important. 


\begin{tabular}{|c|c|c|}
\hline & Number $(n=871)$ & Percent (\%) \\
\hline \multicolumn{3}{|l|}{ AWARENESS of milk banks existence } \\
\hline Aware & 604 & 69.35 \\
\hline Unaware & 267 & 30.65 \\
\hline KNOWLEDGE & Number $(n=604)$ & Percent of correct answers (\%) \\
\hline \multicolumn{3}{|l|}{ Knowledge on places where breast milk can be collected } \\
\hline Know & 26 & 4.30 \\
\hline Don't know & 578 & 95.70 \\
\hline \multicolumn{3}{|l|}{ Knowledge on the number of breast milk banks in Poland } \\
\hline Know & 65 & 10.76 \\
\hline Don't know & 539 & 89.24 \\
\hline \multicolumn{3}{|l|}{ Knowledge on the fact that using milk form the bank is gratuitous } \\
\hline Know & 370 & 61.26 \\
\hline Don't know & 234 & 38.74 \\
\hline \multicolumn{3}{|l|}{ Knowledge on contraindications to breast milk donation } \\
\hline Smoking & 549 & 90.89 \\
\hline HIV & 521 & 86.26 \\
\hline Consumption of large quantities of coffee and tea ( $>3$ cups per day) & 206 & 34.11 \\
\hline Psychiatric diseases & 198 & 32.78 \\
\hline Vegan diet & 46 & 7.62 \\
\hline \multicolumn{3}{|l|}{ Sources of knowledge } \\
\hline The Internet & 415 & 68.71 \\
\hline Television & 146 & 24.17 \\
\hline Friends & 118 & 19.54 \\
\hline Press/radio & 112 & 18.54 \\
\hline Antenatal classes & 62 & 10.26 \\
\hline Nurse/midwife & 62 & 10.26 \\
\hline University classes & 39 & 6.48 \\
\hline Medical doctor & 24 & 3.97 \\
\hline \multicolumn{3}{|l|}{ Women's own assessment of knowledge on breast milk banking } \\
\hline Very good & 0 & 0.00 \\
\hline Good & 20 & 3.31 \\
\hline Average & 275 & 45.53 \\
\hline Bad & 234 & 38.74 \\
\hline Very bad & 75 & 12.42 \\
\hline \multicolumn{3}{|l|}{ Desire to expand knowledge on breast milk banking } \\
\hline Yes & 498 & 57.18 \\
\hline No & 181 & 20.78 \\
\hline Don't know & 192 & 22.04 \\
\hline \multicolumn{3}{|c|}{ Preferred sources used to expand knowledge on breast milk banking $(n=498)^{*}$} \\
\hline Internet & 414 & 83.13 \\
\hline Lecture/conference/meeting in workplace & 182 & 36.55 \\
\hline Midwife/gynaecologist & 108 & 21.69 \\
\hline General Practitioner & 44 & 8.84 \\
\hline Other & 16 & 3.21 \\
\hline
\end{tabular}




\begin{tabular}{|c|c|c|}
\hline & Number $(n=871)$ & Percent (\%) \\
\hline OPINIONS & Number $(n=604)$ & Percent (\%) \\
\hline \multicolumn{3}{|c|}{ Opinion on statement: "feeding premature infants with banked breast milk is a life and health saving procedure" } \\
\hline Agree & 495 & 81.95 \\
\hline Disagree & 42 & 6.95 \\
\hline Neutral & 67 & 11.10 \\
\hline \multicolumn{3}{|c|}{ Opinion on statement: "the number of donors is sufficient in relation to the demand for a banked breast milk" } \\
\hline Agree & 4 & 0.66 \\
\hline Disagree & 478 & 79.14 \\
\hline Neutral & 122 & 20.20 \\
\hline \multicolumn{3}{|c|}{ Opinion on statement: "knowledge on breast milk banking is sufficiently widespread in Poland" } \\
\hline Agree & 6 & 0.99 \\
\hline Disagree & 598 & 99.01 \\
\hline
\end{tabular}

* multiple choice questio

Table 3. Motivations regarding donation among women who were pregnant

\begin{tabular}{|c|c|c|}
\hline & Number (n) & Percent (\%) \\
\hline \multicolumn{3}{|c|}{ Making a donation during lactation $(n=453)$} \\
\hline Made a donation & 9 & 1.99 \\
\hline Didn't make a donation & 444 & 98.01 \\
\hline \multicolumn{3}{|c|}{ Reasons for breast milk donation $(n=9)^{*}$} \\
\hline Milk excess & 8 & 88.89 \\
\hline $\begin{array}{l}\text { Altruism (answer: I wanted to } \\
\text { do something good/I could } \\
\text { be in a similar situation/I knew } \\
\text { an infant in need) }\end{array}$ & 7 & 77.78 \\
\hline \multicolumn{3}{|c|}{ Reasons for not making breast milk donation $(n=444)^{*}$} \\
\hline Lack of milk excess & 168 & 37.84 \\
\hline $\begin{array}{l}\text { Insufficient knowledge about } \\
\text { the procedure }\end{array}$ & 145 & 32.66 \\
\hline $\begin{array}{l}\text { Didn't know about the } \\
\text { existence of breast milk banks } \\
\text { when lactating }\end{array}$ & 113 & 25.45 \\
\hline $\begin{array}{l}\text { Living away from the nearest } \\
\text { milk collection point }\end{array}$ & 76 & 17.12 \\
\hline Counter-attitudinal & 10 & 2.25 \\
\hline
\end{tabular}

According to our best knowledge, the original questionnaire is the very first one to check the knowledge, opinions and attitudes of Polish women on breast milk banks. For several years, women's awareness in this scope has been a subject of interest to scientists. In 2015, Ekşioğlu et al. [12], conducted a survey in Izmir on women's awareness and opinion about banking. The surveyed Polish women are much more aware than the Turkish women of the breast milk banks existence ( $69.3 \%$ and $41.6 \%$, respectively). Polish women most often indicate the Internet as a source of
Table 4. Motivations of childless women regarding donation

\begin{tabular}{|c|c|c|}
\hline & Number (n) & Percent (\%) \\
\hline \multicolumn{3}{|c|}{ Desire to donate breast milk $(n=151)$} \\
\hline Yes & 128 & 84.77 \\
\hline No & 23 & 15.23 \\
\hline \multicolumn{3}{|c|}{ Reasons for the desire of donation $(n=128)^{*}$} \\
\hline Willingness to do something good & 123 & 96.09 \\
\hline $\begin{array}{l}\text { Acquaintance of an infant using } \\
\text { banked breast milk }\end{array}$ & 9 & 7.03 \\
\hline Not to be wasted & 6 & 4.69 \\
\hline Persuaded by family/friends & 1 & 0.78 \\
\hline Fashion & 1 & 0.78 \\
\hline \multicolumn{3}{|c|}{ Reasons for not having a desire of donation $(n=23)^{*}$} \\
\hline $\begin{array}{l}\text { Insufficient knowledge about the } \\
\text { procedure }\end{array}$ & 14 & 60.87 \\
\hline $\begin{array}{l}\text { No consent to feeding another } \\
\text { infant with their own milk }\end{array}$ & 6 & 26.09 \\
\hline Fear of pain while donating & 6 & 26.09 \\
\hline $\begin{array}{l}\text { Living away from the nearest milk } \\
\text { collection point }\end{array}$ & 4 & 17.39 \\
\hline
\end{tabular}

their knowledge (68.5\%). Turkish women also chose the media first (85.7\%). Particular attention is paid to the fact that Polish women, like the Turks, rarely find out about breast milk banks from health care workers (14.2\% and $14.3 \%$, respectively). Another $84.8 \%$ of respondents from the original questionnaire express a willingness to donate milk in the future and $68.8 \%$ of patients surveyed by Ekşioğlu et al. [12], also do.

Polish women, when asked about the reasons why they decided to donate, indicate altruism in $77.8 \%$ of responses 
and $88.9 \%$ also report excessive lactation. The same motivation for donation was indicated by Brazilians surveyed by Alencar and Seidl: $91.7 \%$ and $61.1 \%$ respectively [13]. Alencar and Seidl noticed that human altruism was often the chosen answer, regardless of the socioeconomic status of the respondents. Polish respondents are also often guided

\section{Table 5. Factors influencing the decision to donate}

\begin{tabular}{|l|c|c|}
\hline & \multicolumn{1}{|c|}{$\begin{array}{c}\text { Number } \\
\text { of positive a } \\
\text { nswers }\end{array}$} & $\begin{array}{c}\text { Percentage } \\
\text { of positive } \\
\text { answers (\%) }\end{array}$ \\
\hline \multicolumn{1}{|c|}{ Influence of following factors on the desire of donation $(\mathrm{n}=604)$} \\
\hline $\begin{array}{l}\text { More expanded knowledge } \\
\text { on the procedure }\end{array}$ & 508 & 84.11 \\
\hline $\begin{array}{l}\text { The possibility of donating } \\
\text { breast milk at the nearest } \\
\text { hospital }\end{array}$ & 489 & 80.96 \\
\hline $\begin{array}{l}\text { Privileges (such as for } \\
\text { honorary blood donors) }\end{array}$ & 379 & 62.75 \\
\hline $\begin{array}{l}\text { Payment for breast milk } \\
\text { donation }\end{array}$ & 137 & 22.68 \\
\hline
\end{tabular}

by altruism regardless of their place of residence and level of education.

The medical team surveyed by Wilińska et al. [14], noticed "the need (...) to explain to mother (...) the difference in biological value of pasteurized breast milk and artificial formula". The original questionnaire confirms the correctness of this thesis. Sixty point nine percent of surveyed Polish women indicated that they would not return milk to the breast milk bank due to insufficient knowledge about this procedure. At the same time, $64.1 \%$ of women admit that more expanded knowledge would make them to be a donor. Thus, the most important conclusion from both studies is the positive impact of women's education on their lactation behaviour. Health care workers may therefore play a particularly important role in shaping the attitudes of Polish women on breast milk banks, because nurses and midwives in the original questionnaire turned out to be the most reliable source of knowledge for the respondents.

In review papers, the aspect of factors influencing a positive donation decision is also often discussed. Wesolowska et al. [15], suggest that giving women privileges, such as

Table 6. Awareness of breast milk banks existence depending on the place of residence

\begin{tabular}{|c|c|c|c|c|c|c|c|c|}
\hline \multirow{3}{*}{ Place of residence } & \multicolumn{8}{|c|}{ Awareness of breast milk banks existence } \\
\hline & \multicolumn{2}{|c|}{ Yes } & \multicolumn{2}{|c|}{ No } & \multicolumn{2}{|c|}{ Total } & \multirow{2}{*}{$\mathrm{X}^{2}$} & \multirow{2}{*}{$\mathbf{p}$} \\
\hline & $\mathbf{n}$ & $\%$ & $\mathbf{n}$ & $\%$ & $\mathbf{n}$ & $\%$ & & \\
\hline Village & 80 & 56.74 & 61 & 43.26 & 141 & 100 & \multirow{7}{*}{25.1692} & \multirow{7}{*}{$p=0.00013$} \\
\hline City $<20,000$ & 40 & 64.52 & 22 & 35.48 & 62 & 100 & & \\
\hline City $20,000-50,000$ & 79 & 61.24 & 50 & 38.76 & 129 & 100 & & \\
\hline City $50,000-150,000$ & 90 & 75.00 & 30 & 25.00 & 120 & 100 & & \\
\hline City $150,000-500,000$ & 63 & 70.00 & 27 & 30.00 & 90 & 100 & & \\
\hline City $>500.000$ & 252 & 76.60 & 77 & 23.40 & 329 & 100 & & \\
\hline Total & 604 & 69.35 & 267 & 30.65 & 871 & 100 & & \\
\hline
\end{tabular}

$\mathrm{P}$ - calculated test probability; $\mathrm{X}^{2}$ - Pearson independence test result

Table 7. Awareness of breast milk banks existence depending on the education

\begin{tabular}{|c|c|c|c|c|c|c|c|c|}
\hline \multirow{3}{*}{ Education } & \multicolumn{8}{|c|}{ Awareness of breast milk banks existence } \\
\hline & \multicolumn{2}{|c|}{ Yes } & \multicolumn{2}{|c|}{ No } & \multicolumn{2}{|c|}{ Total } & \multirow{2}{*}{$\mathbf{X}^{2}$} & \multirow{2}{*}{$\mathbf{p}$} \\
\hline & n & $\%$ & n & $\%$ & n & $\%$ & & \\
\hline Primary & 3 & 27.27 & 8 & 72.73 & 11 & 100 & \multirow{8}{*}{45.0137} & \multirow{8}{*}{$<0.00001$} \\
\hline Secondary & 92 & 63.89 & 52 & 36.11 & 144 & 100 & & \\
\hline Vocational & 13 & 52.00 & 12 & 48.00 & 25 & 100 & & \\
\hline Studies in non-medical field & 48 & 50.53 & 47 & 49.47 & 95 & 100 & & \\
\hline Studies in medical field & 41 & 68.33 & 19 & 31.67 & 60 & 100 & & \\
\hline Higher non-medical & 355 & 74.74 & 120 & 25.26 & 475 & 100 & & \\
\hline Higher medical & 52 & 85.25 & 9 & 14.75 & 61 & 100 & & \\
\hline Total & 603 & 69.23 & 267 & 30.65 & 871 & 100 & & \\
\hline
\end{tabular}

$\mathrm{p}-$ calculated test probability; $\mathrm{X}^{2}-$ Pearson independence test result 
Honorary Blood Donors have, could increase the importance of milk banking. A total of $81 \%$ of Poles in the original questionnaire admit that thanks to privileges they would be more willing to give milk.

Wesolowska et al. [15], note that women in difficult lactation situations often ask about the safety of sharing food. According to the authors, they do not find support in healthcare facilities, especially where the activity of breast milk banks is not yet known. We had $16.9 \%$ of surveyed Polish women indicate that the place of residence is too far from the breast milk bank as a reason for not donating. Therefore, it seems important to search for solutions that would facilitate access to lactation counselling and breast milk banks for Polish women living in the villages and in small towns.

The original questionnaire seems to be a valuable source of information that can be used to plan actions to increase women's awareness and knowledge. Most often, the respondents learned about breast milk banks from the Internet, so it is worth using this form of communication for educational purposes. It is also important to increase the role of health care workers in making patients aware of the functioning of breast milk banks and donation. The respondents, who indicated nurses and midwives as the source of knowledge, more often gave correct answers to questions checking their knowledge. Therefore, it can be considered that the information they provide is reliable and updated. The level of awareness of non-medical students is poor. The introduction of optional lectures at universities could be considered as a solution to this issue. Informing women of the breast milk banks existence as early as during their studies or even earlier could provide greater awareness during pregnancy planning. The respondents agree that knowledge about breast milk banking is not sufficiently widespread in Poland. At the same time, they are willing to expand it, mainly via the Internet. Therefore, it is worth thinking about conducting a campaign that would reach a large group of users, who are potential donors, through social media and websites. To increase the frequency of donations, it also seems important to take measures to facilitate access to breast milk banks for Polish women, who give up donation because of distance from the nearest facility.

\section{Limitations of the study}

It seems advisable to extend the original questionnaire. The survey is the very first in Poland to check women's awareness and knowledge about breast milk banking, which makes it impossible to compare the obtained results with other studies conducted on compact samples of respondents. The original questionnaire achieved a significant sample size (871 respondents), but it was not representative in terms of age, education or place of residence. The survey should be treated as a contribution to further research in the field of knowledge, opinions and attitudes of Polish women towards breast milk banks and donations. In subsequent stages it would be advisable to repeat the observation on a representative sample of Polish women. In-depth interviews should be used to expand knowledge of the motives influencing Polish women's donation decisions.

\section{CONCLUSIONS}

The awareness of breast milk banks existence in the studied group is not satisfactory. The knowledge of women about the possibilities and terms of donation is small and cursory. There is a great need for education of Polish women on breast milk banks as it could significantly increase the number of donations. It is worth using the Internet for education. In addition, the role of doctors in raising awareness of the functioning of breast milk banks and donation should be increased. We note the need for further development and creating of breast milk banks and continuous improvement of their availability in Poland.

There are many factors that can increase the level of awareness and frequency of positive donation decisions among Polish women. Therefore, it is worth using the willingness of women to broaden their knowledge. Widely sharing reliable information on banking and promoting the idea of donating breast milk in society can produce impressive results.

\section{Conflict of interest}

The authors state that there are no conflicts of interest to disclose.

\section{REFERENCES}

1. World Health Organization. Guidelines on optimal feeding of low birth-weight infants in low-and middle-income countries. World Health Organization, 2011. https://www.who.int/maternal_child_adolescent/documents/infant_feeding_low_bw/en/?fbclid=IwAR1 oqUilWIAyl36MNb XRQz9U9DVIxxPsdw48gu3vXPUYEWmLAl8ONbtt2N4.

2. Quigley M, Embleton ND, McGuireW, et al. Formula versus donor breast milk for feeding preterm or low birth weight infants. Cochrane Database Syst Rev. 2018;6(6): CD002971, doi: 10.1002/14651858.CD002971.pub4, indexed in Pubmed: 29926476.

3. de Halleux V, Pieltain C, Senterre T, et al. Use of donor milk in the neonatal intensive care unit. Semin Fetal Neonatal Med. 2017; 22(1): 23-29, doi: 10.1016/j.siny.2016.08.003, indexed in Pubmed: 27649995.

4. Weaver G, Bertino E, Gebauer C, et al. Recommendations for the establishment and operation of human milk banks in Europe: a consensus statement from the European Milk Bank Association (EMBA). Front Pediatr. 2019; 7: 53, doi: 10.3389/fped.2019.00053, indexed in Pubmed: 30886837.

5. Fundacja Bank Mleka Kobiecego. Liczy się każda kropla. O karmieniu piersią dla mamy i taty, 2014. http://bankmleka.pl/10-materialy-do-pobrania.html (06/09/2020).

6. Wesołowska A, Pawlus B, Bernatowicz-Łojko U, et al. Funkcjonowanie banków mleka w Polsce - praktyczne rekomendacje. Postępy neonatologii. 2018; 24(1): 59-64. 
7. NANN Board of Directors. NANN Position Statement 3046: The use of human milk and breastfeeding in the neonatal intensive care unit. Adv Neonatal Care. 2009; 9(6): 314-318, doi: 10.1097/ANC.0b013e3181c41ac8, indexed in Pubmed: 20010150.

8. McGuire S. U.S. Dept. of Health and Human Services. The Surgeon General's Call to Action to Support Breastfeeding. U.S. Dept. of Health and Human Services, Office of the Surgeon General. 2011. Adv Nutr. 2011; 2(6): 523-524, doi: 10.3945/an.111.000968, indexed in Pubmed: 22332095.

9. Eidelman Al. Breastfeeding and the use of human milk: an analysis of the American Academy of Pediatrics 2012 Breastfeeding Policy Statement. Breastfeed Med. 2012; 7(5): 323-324, doi: 10.1089/bfm.2012.0067, indexed in Pubmed: 22946888.

10. Arslanoglu S, Corpeleijn W, Moro G, et al. ESPGHAN Committee on Nutrition. Donor human milk for preterm infants: current evidence and research directions. J Pediatr Gastroenterol Nutr. 2013; 57(4): 535-542, doi: 10.1097/MPG.0b013e3182a3af0a, indexed in Pubmed: 24084373.

11. European Milk Bank Association. Joint EMBA and HMBANA statement on milk sharing. 2015. https://europeanmilkbanking.com/joint-embaand-hmbana-statement-on-milk-sharing-has-been-released/?fbclid=
IwARODE0Owo5 DdxYSiOSGMBFofQREp1zzC1 UQFIlijNb0NTOWdhik2op-eZY (06/09/2020).

12. Ekşioğlu $A$, Yeşil $Y$, Turfan EÇ. Mothers' views of milk banking: sample of İzmir. Turk Pediatri Ars. 2015; 50(2): 83-89, doi: 10.5152/tpa.2015.2406, indexed in Pubmed: 26265891.

13. Alencar LC, Seidl EM. Breast milk donation: women's donor experience. Rev Saude Publica. 2009; 43(1): 70-77, doi: 10.1590/s003489102009000100009 , indexed in Pubmed: 19169577.

14. Wilińska M, Borszewska-Kornacka MK, Wesołowska A, et al. Bank mleka kobiecego w Polsce-pierwsze doświadczenia. Standardy Medyczne Pediatria. 2013;10:545-554. http://31.186.81.235:8080/api/files/view/49926.pdf.

15. Wesołowska A, Paczesna I, Studniczek A. Społeczny aspekt funkcjonowaniu banków mleka kobiecego. Standardy Medyczne Pediatria. 2017;14:155-161. https://www.researchgate.net/profile/Anna_Studniczek2/publication/328957097 Spoleczny aspekt funkcjonowania_bankow_mleka_kobiecego/links/5bed46354585150b2bb7a6c2/Spoleczny-aspekt-funkcjonowania-bankow-mlekakobiecego.pdf. 